\title{
DAMPAK STOCK SPLIT TERHADAP HARGA SAHAM DAN AKTIVITAS VOLUME PERDAGANGAN SAHAM DI BURSA EFEK INDONESIA
}

\author{
Ni Kadek Wiwik Yuniartini ${ }^{1}$ \\ Ida Bagus Panji Sedana ${ }^{2}$ \\ ${ }^{1,2}$ Fakultas Ekonomi dan Bisnis Universitas Udayana (Unud), Bali, Indonesia \\ email: wiwikyuniartini@gmail.com
}

\begin{abstract}
ABSTRAK
Stock Split merupakan suatu kegiatan yang dilakukan oleh perusahaan dengan cara memecah nilai nominal saham menjadi lebih kecil. Kebijakan stock split memberikan dampak terhadap harga saham serta aktivitas volume perdagangan saham. Tujuan Penelitian ini adalah untuk mengetahui signifikansi dampak stock split terhadap harga saham dan aktivitas volume perdagangan saham. Penelitian ini dilakukan pada perusahaan-perusahaan yang terdaftar di Bursa Efek Indonesia yang melakukan aksi korporasi berupa stock split periode 2016-2018 dengan 47 sampel. Pengumpulan data dilakukan dengan metode pengumpulan data sekunder yang diperoleh melalui www.idx.co.id. Teknik analisis data menggunakan wilcoxon signed rank test. Hasil penelitian ini menunjukkan bahwa stock split berdampak terhadap harga saham yang dilihat melalui adanya perbedaan yang signifikan harga saham sebelum dan sesudah stock split. Stock split tidak berdampak terhadap aktivitas volume perdagangan saham yang diukur melalui trading volume activity yang menunjukkan tidak ada perbedaan yang signifikan trading volume activity sebelum dan sesudah stock split.

Kata kunci : Stock Split, Harga Saham, Trading Volume Activity.
\end{abstract}

\begin{abstract}
Stock Split is an activity carried out by a company by breaking down the nominal value of shares into smaller ones. Stock split policy has an impact on stock prices and stock trading volume activity. The purpose of this study was to determine the significance of the impact of stock split on stock prices and stock trading volume activity. This research was conducted on companies listed on the Indonesia Stock Exchange with stock split on 2016-2018 with 47 samples. Data collected through www.idx.co.id. Wilcoxon signed rank test was used. The results of this study indicate that stock split has an impact on stock prices seen through a significant difference in stock prices before and after a stock split. Stock split does not have an impact on stock trading volume activity measured through trading volume activity which shows no significant difference in trading volume activity before and after stock split.

Keywords: Stock Split, Stock Price, Trading Volume Activity.
\end{abstract}




\section{PENDAHULUAN}

Pentingnya keberadaan pasar modal saat ini telah dirasakan bagi perekonomian di Indonesia. Sebagai tren umum, kinerja pasar modal dipandang sebagai indikator atau prediktor ekonomi. Periode kenaikan konstan dalam hargaharga saham menandakan periode pertumbuhan bagi ekonomi sedangkan periode penurunan yang konstan menandakan periode perlambatan (Jyoti, 2014). Perkembangan pasar modal di Indonesia sangatlah pesat. Hal ini ditunjukkan dengan banyaknya perusahaan yang terdaftar di Bursa Efek Indonesia (BEI) serta banyak masyarakat yang terjun ke pasar modal. Pasar modal merupakan sarana perusahaan untuk meningkatkan kebutuhan dana jangka panjang dengan menjual saham atau mengeluarkan obligasi. Menurut Azis dan Nadir (2015) pasar modal merupakan pasar untuk berbagai instrumen keuangan jangka panjang yang bisa diperjual belikan baik surat utang (obligasi), ekuiti (saham), reksadana, instrumen derivatif maupun instrumen lainnya.

Pasar modal memainkan peran yang signifikan dalam pembangunan ekonomi di era milenium ini yaitu sebagai sarana untuk mendapatkan dana dari pihak investor yang kemudian akan digunakan oleh emiten untuk mengembangkan usaha yang sering kita kenal dengan fungsi ekonomi. Selanjutnya, fungsi keuangan yaitu sebagai sarana bagi masyarakat umum untuk berinvestasi ke dalam instrumen keuangan seperti saham dan obligasi yang mempunyai tingkat pengembalian yang tinggi. Aktivitas pasar modal yang optimal diharapkan bisa menjadi mediator antara masyarakat sebagai penyedia dana dan perusahaan emiten sebagai pihak yang membutuhkan dana.

Dewasa ini sudah banyak perusahaan yang mengubah status perusahaannya menjadi perusahaan go public dan mendaftarkan sahamnya di pasar modal. Perusahaan yang sudah go public tentunya memiliki keinginan untuk mampu meningkatkan nilai perusahaannya. Peningkatan harga saham merupakan salah satu cara yang digunakan oleh perusahaan untuk meningkatkan nilai perusahaannya. Hal ini dikarenakan harga pasar dari saham menjadi cerminan dari nilai perusahaan tersebut. Akan tetapi, peningkatan harga saham yang dinilai terlalu tinggi di pasar mengakibatkan menurunnya kemampuan investor untuk membeli saham. Untuk itu, beberapa perusahaan melakukan corporate action.

Informasi mengenai corporate action memegang peranan yang vital di pasar modal. Corporate action merupakan aktivitas emiten yang berpengaruh terhadap jumlah saham yang beredar dan berpengaruh terhadap harga saham di pasar (Darmadji dan Hendy M., 2012: 123). Corporate action merupakan berita yang umumnya menyedot perhatian pihak-pihak yang terkait di pasar modal, khususnya para pemegang saham. Keputusan corporate action dapat mempengaruhi jumlah saham yang beredar serta jumlah pemegang sahamnya. Untuk mengambil keputusan corporate action dibutuhkan Rapat Umum Pemegang Saham (RUPS) agar kebijakan yang dilakukan dapat berjalan dengan efektif. Salah satu kebijakan corporate action yang dapat diambil adalah stock split (pemecahan saham). Secara umum, pemecahan saham dilakukan perusahaan ketika harga saham terlalu mahal dan investor sulit untuk berinvestasi, sehingga diharapkan dengan pemecahan saham akan lebih meningkatkan permintaan saham itu sendiri (Bhuvaneswari dan Ramya, 2014). 
Stock split merupakan sebuah aksi korporasi yang dilakukan perusahaan yang telah go public (emiten) untuk memecahkan nilai nominal saham kedalam nilai nominal yang lebih kecil, dengan cara memecahkan selembar saham menjadi beberapa lembar saham. Manajemen melakukan stock split dengan anggapan bahwa saham dipecah untuk menjaga agar harga saham tidak terlalu mahal. Peristiwa stock split dianggap sebagai good news yang diberikan perusahaan kepada pasar, karena peristiwa tersebut dapat meningkatkan harapan investor tentang laba masa depan perusahaan (Tabibian, 2014). Investor yang merespon informasi sebagai good news akan lebih banyak melakukan pembelian saham, dan apabila direspon sebagai bad news maka banyak investor cenderung menjual sahamnya agar tidak mengalami kerugian yang lebih banyak (Kemraj dan Sukrishnalall, 2014).

Motivasi perusahaan melakukan stock split adalah meningkatkan harga dan likuiditas saham emiten melalui peningkatan volume perdagangan saham. Harga saham yang rendah akan menarik minat investor kecil untuk melakukan investasi. Sementara harga saham yang terlalu tinggi akan menurunkan minat investor untuk membeli saham perusahaan yang bersangkutan. Terlebih lagi investor perorangan, mereka mungkin akan mencari saham perusahaan lain yang harganya lebih menarik dan diprediksi akan memberikan keuntungan yang besar. Peristiwa stock split ini juga dianggap sebagai sinyal yang positif karena manajer perusahaan akan menyampaikan prospek masa depan yang baik dari perusahaan ke publik yang belum mengetahuinya. Alasan sinyal ini didukung dengan kenyataan bahwa perusahaan yang melakukan stock split merupakan perusahaan yang mempunyai kinerja yang baik (Dwimulyani, 2018). Para investor yang menganggap bahwa stock split dilakukan oleh perusahaan yang memiliki kinerja yang baik tentu akan menerima berita tersebut dengan melakukan pembelian saham.

Informasi yang tersedia di pasar dibutuhkan oleh investor dalam menentukan keputusannya berinvestasi. Ketika pasar bereaksi dengan cepat dan akurat untuk mencapai harga keseimbangan baru yang sepenuhnya mencerminkan informasi yang tersedia, maka kondisi pasar ini disebut pasar efisien. Informasi yang digunakan untuk menilai pasar yang efisien adalah informasi yang dipublikasikan sebagai suatu peristiwa atau yang disebut studi peristiwa. Event study atau studi peristiwa ini menggambarkan sebuah teknik riset keuangan empiris yang memungkinkan seorang pengamat menilai dampak dari suatu peristiwa terhadap harga saham maupun aktivitas volume perdagangan saham pada suatu perusahaan. Event study dalam hal ini juga dapat digunakan untuk menguji kandungan informasi (information content) dari peristiwa stock split. Jika pengumuman stock split mengandung informasi (information content), maka diharapkan pasar akan bereaksi pada waktu peristiwa stock split itu terjadi.

Prediksi harga saham merupakan masalah penting dan menantang dalam analisis pasar modal (Hua et al., 2016). Pergerakan harga saham menjadi topik utama di pasar keuangan dan telah menarik perhatian luas tidak hanya dari para trader tetapi juga para periset. Dalam trading range theory menyatakan bahwa stock split akan membawa harga saham pada tingkat yang lebih menarik bagi investor, sehingga saham akan menjadi lebih likuid serta dengan meningkatnya permintaan saham akan meningkatkan harga saham (Hossain, 2017). Investor percaya bahwa 
pemecahan saham akan menghasilkan kenaikan harga saham karena pembelian saham yang meningkat, serta dapat menghasilkan return yang lebih (Jay, 2016).

Studi peristiwa yang dilakukan pada 12 perusahaan di Bombay Stock Exchange menunjukkan hasil bahwa pemecahan saham berdampak positif pada harga saham yang ditunjukkan dengan adanya kenaikan harga setelah peristiwa stock split. Hasil penelitian serupa juga diperoleh Gajera et al. (2017) yang menyimpulkan bahwa stock split berdampak positif terhadap harga saham. Penelitian-penelitian tersebut berarti bahwa terdapat perbedaan harga saham sebelum dan sesudah stock split. Hasil penelitian yang sama juga diperoleh Arifandi (2014), Mediyanto (2015), Jasmine dan Herlambang (2015), Fauzi dkk. (2016) dan Zeky (2018) yang menyatakan bahwa stock split menunjukkan perbedaan yang signifikan terhadap harga saham.Namun beberapa penelitian menyebutkan bahwa stock split dikatakan merupakan tindakan yang tidak memiliki nilai ekonomis yang seharusnya tidak merubah harga saham. Penelitian-penelitian tersebut diantaranya dilakukan oleh Mahala dkk. (2015), Khajar (2016), Kesuma \& Adnan (2018), yang menyatakan bahwa tidak ada perbedaan yang signifikan antara harga saham sebelum dan sesudah stock split.

Pemecahan saham diharapkan akan mampu menjaga tingkat perdagangan saham dalam rentang yang optimal dan menjadikan saham lebih likuid. Harga saham yang murah akan menyebabkan investor kecil mampu untuk membelinya sehingga hal ini dapat meningkatkan aktivitas volume perdagangan saham. Volume perdagangan saham merupakan salah satu alat yang dapat digunakan untuk melihat ada atau tidaknya reaksi pasar terhadap suatu peristiwa tertentu, untuk melihat pengaruh pemecahan saham terhadap volume perdagangan saham dilihat dari aktivitas volume perdagangan saham yang bersangkutan yang diukur dengan menggunakan TVA yaitu perbandingan antara jumlah saham yang diperdagangkan dengan jumlah lembar saham yang beredar (Khajar, 2016). Semakin besar nilai TVA maka menunjukkan bahwa semakin banyak jumlah lembar saham yang diperdagangkan.

Studi dampak stock split terhadap aktivitas volume perdagangan saham dilakukan pada Bursa Efek India untuk 34 peristiwa stock split menunjukkan bahwa, volume perdagangan saham menurun setelah peristiwa stock split. Hal ini berarti pasar tidak memberikan reaksi yang baik terhadap peristiwa pemecahan saham tersebut. Selain itu, banyak studi peristiwa dilakukan oleh para peneliti mengenai dampak stock split terhadap aktivitas volume perdagangan saham yang menunjukkan hasil yang bervariatif Diantaranya Arifandi (2014), Mediyanto (2015), Fauzi dkk. (2016), Korir et al. (2016), serta Zeky (2018) yang menemukan hasil bahwa terdapat perbedaan yang signifikan volume perdagangan saham sebelum dan sesudah stock split. Namun, penelitian tersebut bertentangan dengan penelitian yang dilakukan oleh Mahala et al. (2015), Khajar (2016), Anggraini dan Wiagustini (2015), Nadig (2015) serta Fauzi dkk. (2016) yang menyimpulkan bahwa tidak terdapat perbedaan yang signifikan antara volume perdagangan saham sebelum dan sesudah stock split.

Berdasarkan hasil penelitian yang berbeda-beda tersebut, maka dilakukan penelitian lebih lanjut untuk mengetahui apakah terdapat perbedaan yang signifikan 
dari pemecahan saham (stock split) terhadap harga saham dan aktivitas volume perdagangan saham di Bursa Efek Indonesia.

Alasan dari perusahaan melakukan stock split dijelaskan oleh dua teori yaitu: Teori sinyal berargumen bahwa stock split menunjukkan sinyal optimisme manajemen akan mampu meningkatkan kembali harga saham dimasa datang (Tandelilin, 2010: 570). Manajer mengambil keputusan stock split dengan tujuan untuk memberikan sinyal pada investor, dimana terdapat asimetri informasi antara manajer dan investor. Investor biasanya merespon informasi yang diterima tersebut secara berbeda. Stock split memberikan sinyal positif karena manajer perusahaan akan menginformasikan prospek masa depan yang baik dari perusahaan kepada publik yang belum mengetahuinya. Alasan ini didukung dengan adanya kenyataan bahwa perusahaan yang melakukan kebijakan stock split adalah perusahaan yang memiliki kinerja yang baik. Sehingga ketika pasar beraksi terhadap pengumuman stock split, reaksi ini terjadi karena investor mengetahui prospek masa depan perusahaan yang bersangkutan. Pasar akan merespon sinyal yang positif jika pemberi sinyal kredible. Sinyal yang diberikan oleh perusahaan yang memiliki kinerja masa lalu yang buruk tidak akan dipercaya pasar.

Teori berikutnya adalah Trading Range Theory. Teori ini menyatakan bahwa stock split akan membawa harga saham pada tingkat yang lebih menarik bagi investor, sehingga saham akan menjadi lebih likuid dan dengan meningkatnya permintaan saham akan meningkatkan harga saham (Tandelilin, 2010: 576). Harga saham yang baru pasca split diharapkan dapat meningkatkan minat investor untuk membeli saham tersebut sehingga likuiditas saham menjadi meningkat. Secara umum, harga saham yang terlalu tinggi mengurangi kemampuan investor dalam membeli saham tersebut. Dengan adanya stock split, diharapkan akan meningkatkan daya beli investor terhadap saham tersebut. Bila daya beli investor meningkat, maka harga saham pun bisa terkerek naik. Namun, perusahaan yang melakukan stock split saham tidak selalu sahamnya mengalami dampak positif. Beberapa saham setelah stock split mengalami penguatam, namun beberapa lainnya mengalami pelemahan secara signifikan.

Murahnya saham yang dapat dinikmati oleh investor retail dapat menambah likuiditas, namun aktivitas pemodal kecil yang sangat aktif bertransaksi justru malah menahan lajunya kenaikan harga. Selain itu naik turunnya harga saham setelah stock split tentunya juga dipengaruhi faktor lain di luar stock split itu sendiri, baik fundamental perusahaan, maupun trend sektor dan industrinya. Harga saham terbentuk karena adanya interaksi para penjual dan pembeli saham yang dilatar belakangi oleh harapan mereka terhadap profit perusahaan. Hal tersebut menyebabkan para investor membutuhkan informasi yang berkaitan dengan pembentukan harga saham yang digunakan sebagai pertimbangan dalam pengambilan keputusan untuk menjual atau membeli saham. Harga saham di bursa sangat ditentukan oleh kekuatan pasar, yang berarti kekuatan permintaan dan penawaran. Permintaan dan penawaran atas saham berfluktuasi setiap harinya maka harga saham pun akan mengikuti pola fluktuasi tersebut. Ketika permintaan saham lebih banyak, harga saham akan cenderung meningkat, sedangkan pada kondisi dimana penawaran saham lebih banyak, harga saham akan cenderung menurun. Harga saham mencerminkan prestasi emiten, pergerakan harga saham searah 
dengan kinerja emiten. Apabila emiten memiliki kinerja yang baik, maka harga saham akan cenderung naik. Begitu sebaliknya, apabila emiten memiliki kinerja buruk, maka harga saham bisa menurun. Harga saham mencerminkan nilai suatu perusahaan. Perusahaan yang memiliki harga saham yang tinggi, maka perusahaan tersebut dinilain tinggi pula. Dengan adanya penilaian saham ini para investor dapat menentukan strategi investasi melalui keputusan membeli, menjual atau mempertahankan sahamnya.

Setiap perusahaan yang akan menerbitkan saham sangat memperhatikan harga sahamnya. Harga saham yang terlalu rendah seringkali diartikan bahwa kinerja perusahaan yang bersangkutan kurang baik. Sedangkan, bila harga saham terlalu tinggi hal tersebut akan mempengaruhi kemampuan investor dalam membelinya sehingga saham tersebut menjadi kurang likuid dan menyebabkan harga saham sulit untuk mengalami peningkatan. Karena itulah banyak perusahaan melakukan split terhadap sahamnya dengan tujuan agar daya beli investor serta harga saham dapat mengalami peningkatan.

Penelitian yang dilakukan oleh Gajera et al. (2017) yang dilakukan pada perusahaan-perusahaan yang mengalami stock split di Bombay Stock Exchange menemukan bahwa stock split memberikan dampak positif pada harga saham serta meningkatkan likuiditas yang mengarah pada pengembalian yang lebih tinggi setelah peristiwa stock split. Penelitian yang dilakukan oleh Gao dan Zhiyu (2018) yang melakukan penelitian pada 159 perusahaan stock split di Pasar China menyimpulkan bahwa sebelum terjadinya stock split tidak memberikan pengaruh yang signifikan terhadap harga saham sehingga hal tersebut dikatakan tidak berkolerasi.

Sementara setelah pengumuman stock split memberikan dampak yang signifikan terhadap harga saham, sehingga memiliki hubungan yang berkolerasi. Setiawan dan Atikah (2018) yang melakukan penelitian pada perusahaan stock split di Bursa Efek Indonesia menemukan hasil yang sama bahwa aktivitas stock split memiliki pengaruh yang signifikan terhadap harga saham. Arifandi (2014), Mediyanto (2015), Fauzi dkk. (2016), dan Zeky (2018) juga menemui hasil yang sama. Penelitian-penelitian tersebut bertentangan dengan penelitian yang dilakukan oleh Osama dan Mervat (2017) yang melakukan penelitian pada 51 perusahaan yang mengalami stock split di Pasar Saham Mesir menemukan hasil bahwa peristiwa stock split tidak memberikan dampak terhadap harga saham. Penelitian tersebut selaras dengan penelitian yang dilakukan oleh Mahala dkk. (2015), Khajar (2016), Kesuma \& Adnan (2018)

Volume perdagangan saham atau trading volume activity merupakan rasio antara jumlah lembar saham yang diperdagangkan pada waktu tertentu terhadap jumlah saham yang beredar pada waktu tertentu (Sudirman, 2015: 117). Volume perdagangan saham dapat diketahui dengan membandingkan jumlah saham perusahaan yang diperdagangkan pada periode tertentu dengan jumlah saham yang beredar pada waktu tertentu.Naiknya volume perdagangan merupakan kenaikan aktivitas jual beli para investor di bursa. Semakin meningkat volume penawaran dan permintaan suatu saham, semakin besar pengaruhnya terhadap fluktuasi harga saham di bursa dan semakin meningkatnya aktivitas volume perdagangan saham 
menunjukkan semakin diminatinya saham tersebut oleh investor sehingga membawa pengaruh terhadap naiknya harga dan return saham.

Penelitian yang dilakukan oleh Ginting dan Rahyuda (2014) menemukan bahwa terdapat perbedaan volume perdagangan yang signifikan setelah terjadinya peristiwa stock split. Penelitian ini selaras dengan penelitian yang dilakukan oleh Safira dan Febriyanti (2016) yang menyimpulkan bahwa volume \& frekuensi perdagangan pada perusahaan-perusahaan yang mengalami stock split mengalami perbedaan yang signifikan. Menurut Jaelani (2013) aktivitas stock split menyebabkan peningkatan volume perdagangan sehingga perdagangan saham menjadi lebih likuid. Arifandi (2014), Mediyanto (2015), Fauzi dkk. (2016), serta Zeky (2018) juga menemukan hasil yang sama bahwa stock split berdampak positif terhadap volume perdagangan saham di Bursa Efek Indonesia. Namun Mitesh et al. (2016) yang melakukan penelitian pada Bursa Efek India terhadap perusahaanperusahaan yang mengalami stock split yang diumumkan pada 1 Januari 2016 hingga 31 Juli 2016 menemukan hasil yang berbeda bahwa pengumuman stock split justru mengakibatkan penurunan rasio volume perdagangan. Sementara penelitian yang dilakukan oleh Mahala dkk. (2015), Khajar (2016), Anggraini dan Wiagustini (2015), Nadig (2015), Fauzi dkk. (2016) serta Yustisia (2018) menyimpulkan bahwa tidak terdapat perbedaan yang signifikan volume perdagangan sebelum dan sesudah stock split.

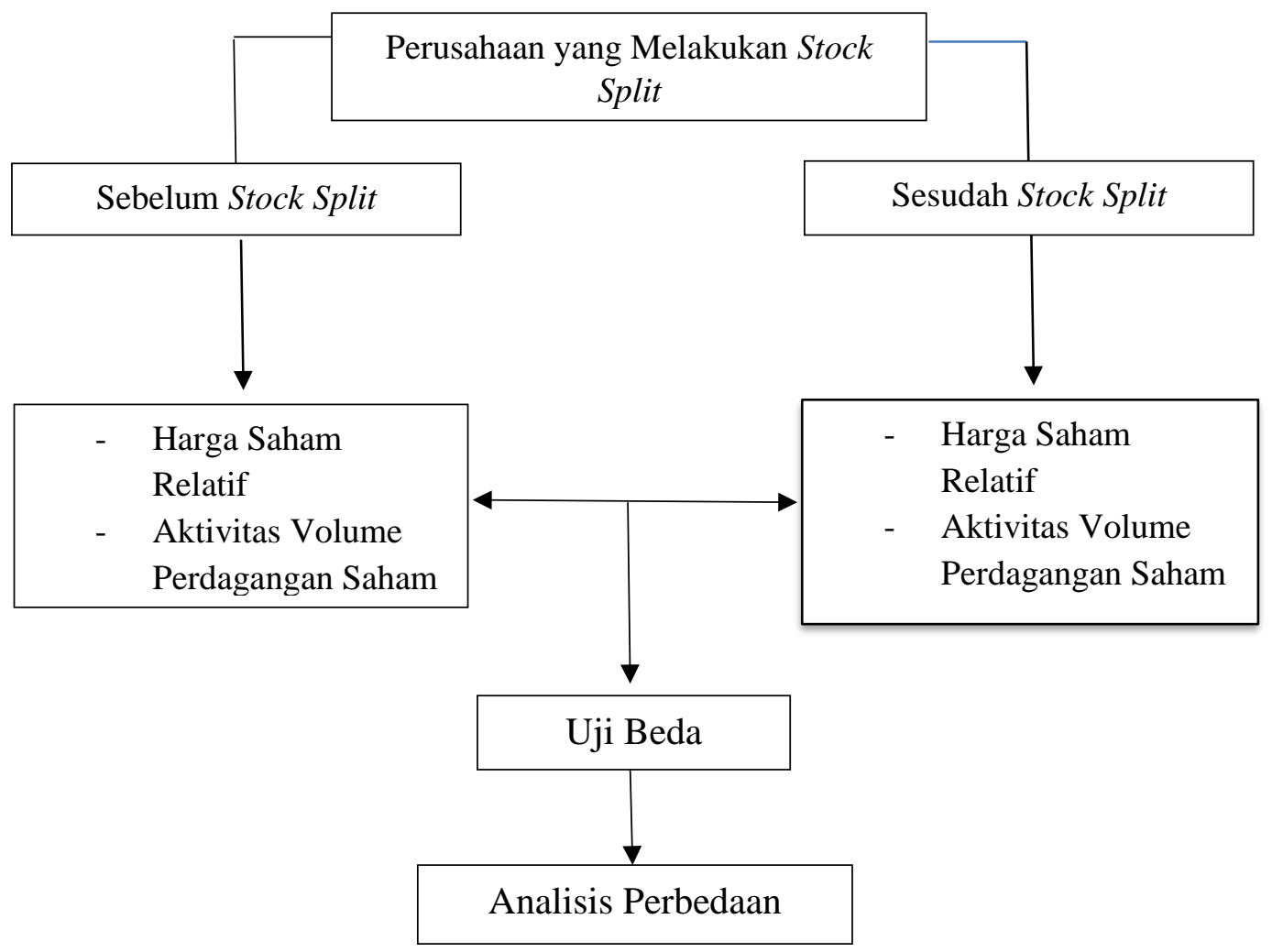

Gambar 1. Kerangka Konseptual 
Harga saham yang terlalu tinggi menyebabkan saham tersebut sulit untuk diperdagangkan. Maka dari itu suatu perusahaan mengambil kebijakan stock split agar harga saham menjadi lebih terjangkau dan minat investor akan meningkat untuk melakukan investasi. Dalam signaling theory menyatakan bahwa stock split menunjukkan sinyal optimism manajemen akan mampu meningkatkan kembali harga saham dimasa yang akan datang. Investor percaya bahwa pemecahan saham akan menghasilkan kenaikan harga saham serta dapat menghasilkan return yang lebih (Jay, 2016). Investor yang merespon kebijakan stock split sebagai good news maka akan melakukan pembelian saham lebih banyak lagi.

Sementara investor yang merespon kebijakan stock split sebagai bad news maka investor tersebut justru akan menjual sahamnya agar tidak mendatangkan kerugian lebih banyak lagi. Gajera et al. (2017) melakukan penelitian pada perusahaan-perusahaan yang mengalami stock split di Bombay Stock Exchange dengan hasil penelitiannya yaitu stock split memberikan dampak positif pada harga saham serta meningkatkan likuiditas yang akan mengarah pada pengembalian yang lebih tinggi setelah peristiwa stock split. Penelitian yang dilakukan oleh Setiawan dan Atikah (2018) pada perusahaan stock split di Bursa Efek Indonesia dengan menggunakan test dua rata-rata yang berbeda serta regresi berganda menemukan hasil bahwa aktivitas stock split menyebabkan peningkatan harga saham. Hasil penelitian yang dilakukan oleh Mittal (2015) juga menyimpulkan bahwa stock split menunjukkan perbedaan yang signifikan terhadap harga saham. Studi tersebut menemukan bahwa pasar bereaksi positif terhadap sinyal stock split dan menganggap pemecahan saham ini sebagai berita baik yang berdampak pada kenaikan harga saham setelah pengumuman stock split yang ditunjukkan dengan adanya perbedaan harga saham sebelum dan sesudah stock split. Arifandi (2014), Mediyanto (2015), Masry (2015), Fauzi dkk. (2016) dan Zeky (2018) juga menemui hasil yang sama. Sehingga hipotesis untuk penelitian ini dapat dirumuskan sebagai berikut :

$\mathrm{H}_{1}$ : Terdapat perbedaan yang signifikan antara harga saham sebelum dan setelah peristiwa stock split.

Ketika harga saham menurun akibat pemecahan saham tersebut, maka minat investor untuk melakukan investasi akan meningkat yang artinya bahwa volume perdagangan saham juga akan meningkat. Peristiwa pemecahan saham (stock split) ini berdampak atau tidaknya terhadap volume perdagangan dapat diukur melalui trading volume activity. Apabila terdapat perbedaan TVA sebelum dan sesudah pengumuman stock split, berarti stock split berdampak terhadap aktivitas volume perdagangan saham. Begitu sebaliknya, apabila tidak terdapat perbedaan TVA sebelum dan sesudah stock split maka peristiwa stock split tidak berdampak terhadap aktivitas volume perdagangan saham. Penelitian yang dilakukan oleh Ginting dan Rahyuda (2014), Safira dan Febriyanti (2016) menyimpulkan bahwa volume dan frekuensi perdagangan pada perusahaan-perusahaan yang mengalami stock split menunjukkan perbedaan yang signifikan. Penelitian yang dilakukan Patel et al. (2016) juga menemukan bahwa pemecahan saham menunjukkan perbedaan signifikan terhadap aktivitas volume perdagangan saham. Hal ini ditunjukkan dengan menurunnya rasio volume perdagangan saham setelah pengumuman stock split. Arifandi (2014), Mediyanto (2015), Fauzi dkk. (2016), 
Korir et al. (2016), Utami (2017), serta Zeky (2018) juga menemukan hasil yang sama bahwa stock split berdampak positif terhadap volume perdagangan saham di Bursa Efek Indonesia yang ditunjukkan dengan adanya perbedaan volume perdagangan saham sebelum dan sesudah peristiwa stock split. Berdasarkan hasil penelitian pendukung tersebut, maka dapat dirumuskan hipotesis sebagai berikut $\mathrm{H}_{2}$ : Terdapat perbedaan yang signifikan antara volume perdagangan saham sebelum dan sesudah stock split.

\section{METODE PENELITIAN}

Penelitian ini merupakan penelitian dalam kategori studi peristiwa (event study). Penelitian ini juga menggunakan pendekatan komparatif. Penelitian ini dilakukan pada perusahaan-perusahaan yang melakukan stock split dan terdaftar di Bursa Efek Indonesia (BEI) periode 2016-2018. Pemilihan lokasi di Bursa Efek Indonesia ditetapkan karena perusahaannya yang terbuka sehingga memudahkan dalam memperoleh data yang diperlukan, selain itu data-data yang dipublikasikan juga lebih akurat karena terseleksi dan diawasi oleh Otoritas Jasa Keuangan (OJK). Objek penelitian ini adalah mengenai harga saham dan aktivitas volume perdagangan saham terhadap peristiwa stock split (pemecahan saham) pada perusahaan-perusahaan yang terdaftar di Bursa Efek Indonesia (BEI) periode 20162018.Ditinjau dari rumusan masalah dan hipotesis yang telah diuraikan diatas, maka variabel yang akan dianalisis dalam penelitian ini adalah harga saham dan aktivitas volume perdagangan saham. Variabel ini akan diamati selama periode jendela 11 hari termasuk hari h pemecahan ( 5 hari sebelum, hari h, dan 5 hari sesudah pemecahan saham).

Harga saham yang dimaksud dalam penelitian ini ialah harga saham relatif sebelum peristiwa stock split yaitu $\mathrm{H}-1$ sampai $\mathrm{H}-5$ serta harga saham relatif setelah stock split yaitu hari $\mathrm{H}$ hingga $\mathrm{H}+5$ pada perusahaan-perusahaan yang melakukan kebijakan stock split periode 2016-2018. Harga saham relatif sebelum stock split diperoleh dari perbandingan antara closing price dari $\mathrm{H}-1$ hingga $\mathrm{H}-5$ dengan split factor. Sementara harga saham relatif sesudah stock split merupakan closing price hari $\mathrm{H}$ hingga $\mathrm{H}+5$. Satuan harga pasar saham relatif sebelum dan sesudah stock split yang digunakan ialah rupiah. Adapun rumus harga pasar saham relatif sebelum dan sesudah stock split ialah:

\section{Harga saham relatif sebelum stock split:}

$\mathrm{HR}_{\mathrm{i}, \mathrm{t}}=$

$\frac{P_{\mathrm{t}}}{\mathrm{n}}$.

Keterangan :

$\mathrm{HR}_{\mathrm{i}, \mathrm{t}}=$ Harga pasar saham relatif sebelum stock split $\mathrm{i}$ pada waktu $\mathrm{t}$

$\mathrm{P} \quad=$ Harga sebelum pemecahan saham (closing price harian) pada waktu $\mathrm{t}$

$\mathrm{n} \quad=$ Split factor

$\mathrm{i} \quad=$ Nama perusahaan

$\mathrm{t}=$ Waktu tertentu ( $\mathrm{H}-1$ hingga $\mathrm{H}-5$ sebelum stock split)

\section{Harga saham relatif sesudah stock split:}


$\mathrm{HRS}_{\mathrm{i}, \mathrm{t}}=\mathrm{PS}_{\mathrm{t}}$

Keterangan :

$\mathrm{HRS}_{\mathrm{i}, \mathrm{t}}=$ Harga saham relatif sesudah stock split perusahaan i pada waktu $\mathrm{t}$

PPS $_{\mathrm{t}} \quad=$ Harga saham sesudah stock split (closing price harian) pada waktu $\mathrm{t}$

$\mathrm{i} \quad=$ Nama perusahaan

$\mathrm{t} \quad=$ Waktu tertentu (hari $\mathrm{H}$ hingga $\mathrm{H}+5$ sesudah stock split)

Penelitian ini menggunakan trading volume activity untuk mengukur aktivitas volume perdagangan saham sebelum dan sesudah stock split. Data mengenai jumlah saham terjual serta jumlah saham perusahaan beredar merupakan volume transaksi harian selama 5 hari sebelum, hari h dan 5 hari sesudah stock split untuk perusahaan-perusahaan yang melakukan stock split periode 2016-2018. Satuan TVA yang digunakan adalah dalam bentuk persentase.

$\mathrm{TV}_{i, t}=\frac{\text { Saham perusahaan } \mathrm{i} \text { yang diperdagangkan pada waktu } \mathrm{t}}{\text { Saham perusahaan } \mathrm{i} \text { yang beredar pada waktu } \mathrm{t}}$

Keterangan :

$\mathrm{TV} A_{i, t}=$ Aktivitas perdagangan saham i pada hari ke $\mathrm{t}$

$\mathrm{i}=$ Nama perusahaan

$\mathrm{t}=$ Waktu tertentu

Populasi pada penelitian ini adalah perusahaan-perusahaan yang terdaftar di Bursa Efek Indonesia (BEI), yang melakukan stock split pada tahun 2016-2018. Adapun metode penentuan sampel yang digunakan dalam penelitian ini adalah sampling jenuh atau sensus. Jumlah sampel pada penelitian ini adalah sebanyak 47 perusahaan. Metode pengumpulan data dalam penelitian ini menggunakan data sekunder yang diperoleh melalui website resmi Bursa Efek Indonesia (BEI) dengan alamat website www.idx.co.id, www.yahoofinance.com, dan www.sahamok.com untuk memperoleh informasi serta data yang diperlukan mengenai perusahaanperusahaan yang melakukan stock split.

Dalam penelitian ini data kualitatif yang digunakan adalah daftar nama perusahaan yang melakukan stock split dan terdaftar di Bursa Efek Indonesia (BEI) periode 2016-2018. Dalam penelitian ini data kuantitatif yang digunakan adalah : 1) Tanggal peristiwa stock split yang digunakan sebagai event date (t0). 2) Harga saham penutupan harian (closing price) perusahaan yang melakukan stock split dalam periode pengamatan, yaitu 5 hari sebelum pemecahan, hari h, dan 5 hari sesudah pemecahan saham (stock split). 3) Jumlah saham yang diperdagangkan secara harian. 4) Jumlah saham yang beredar atau listing share. 5) Nilai nominal saham sebelum stock split. 6) Nilai nominal saham setelah stock split. Dalam penelitian ini sumber data diperoleh melalui situs www.idx.co.id, www.yahoofinance.com, dan www.sahamok.com.

\section{HASIL DAN PEMBAHASAN}


Tabel 1.

Deskripsi Data Harga Saham

\begin{tabular}{lcrccr}
\hline & N & Minimum & Maximum & Mean & $\begin{array}{c}\text { Std. } \\
\text { Deviation }\end{array}$ \\
\hline $\mathrm{H}-5$ & 47 & 128.000 & 8725.000 & 1148.806 & 1823.206 \\
$\mathrm{H}-4$ & 47 & 129.000 & 8600.000 & 1149.702 & 1815.843 \\
$\mathrm{H}-3$ & 47 & 131.300 & 8687.500 & 1168.774 & 1826.656 \\
$\mathrm{H}-2$ & 47 & 131.300 & 8775.000 & 1176.940 & 1831.878 \\
$\mathrm{H}-1$ & 47 & 131.100 & 8950.000 & 1202.998 & 1861.147 \\
$\mathrm{H}$ & 47 & 130.000 & 9000.000 & 1173.745 & 1849.875 \\
$\mathrm{H}+1$ & 47 & 129.000 & 8850.000 & 1170.425 & 1834.089 \\
$\mathrm{H}+2$ & 47 & 120.000 & 8925.000 & 1166.681 & 1843.822 \\
$\mathrm{H}+3$ & 47 & 120.000 & 8800.000 & 1175.106 & 1830.358 \\
$\mathrm{H}+4$ & 47 & 122.000 & 8800.000 & 1175.276 & 1829.908 \\
$\mathrm{H}+5$ & 47 & 125.000 & 8850.000 & 1177.489 & 1833.416 \\
Valid N & 47 & & & & \\
(listwise) & & & & & \\
\hline Sumber: Data Diolah 2019 & & & & &
\end{tabular}

Tabel 1. menjelaskan nilai maksimum, minimum rata-rata serta standar deviasi. Pada H-5 nilai minimum sebesar 128.000 yang didapat oleh perusahaan Kedaung Indah Can Tbk dan nilai maksimum sebesar 8725.000 pada H-5 didapat oleh perusahaan Indofood CBP Sukses Makmur Tbk. Rata-rata harga saham relatif H-5 bernilai positif sebesar 1148.806 dan standar deviasinya sebesar 1823.206. Pada H-4 nilai minimum sebesar 129.000 didapat oleh perusahaan Kedaung Indah Can Tbk dan nilai maksimum sebesar 8600.000 diperoleh perusahaan Indofood CBP Sukses Makmur Tbk. Rata-rata harga saham relatif bernilai positif yaitu sebesar 1149.702 serta standar deviasinya sebesar 1815.843.Pada H-3 nilai minimum sebesar 131.300 didapat oleh perusahaan Betonjaya Manunggal Tbk dan nilai maksimum sebesar 8687.500 diperoleh perusahaan Indofood CBP Sukses Makmur Tbk. Rata-rata harga saham relatif bernilai positif yaitu sebesar 1168.774 serta standar deviasinya sebesar 1826.656.

Pada H-2 nilai minimum sebesar 131.300 didapat oleh perusahaan Betonjaya Manunggal Tbk dan nilai maksimum sebesar 8775.000 diperoleh perusahaan Indofood CBP Sukses Makmur Tbk. Rata-rata harga saham relatif bernilai positif yaitu sebesar 1176.940 serta standar deviasinya sebesar 1831.878. Pada H-1 nilai minimum sebesar 131.100 didapat oleh perusahaan Betonjaya Manunggal Tbk dan nilai maksimum sebesar 8950.000 diperoleh perusahaan Indofood CBP Sukses Makmur Tbk. Rata-rata harga saham relatif bernilai positif yaitu sebesar 1861.147 serta standar deviasinya sebesar 1861.147. Pada hari $\mathrm{H}$ nilai minimum sebesar 130.000 didapat oleh perusahaan Betonjaya Manunggal Tbk dan nilai maksimum sebesar 9000.000 diperoleh perusahaan Indofood CBP Sukses Makmur Tbk. Ratarata harga saham relatif bernilai positif yaitu sebesar 1173.745 serta standar deviasinya sebesar 1849.875. Pada $\mathrm{H}+1$ nilai minimum sebesar 129.000 didapat oleh perusahaan Betonjaya Manunggal Tbk dan nilai maksimum sebesar 8850.000 diperoleh perusahaan Indofood CBP Sukses Makmur Tbk. Rata-rata harga saham relatif bernilai positif yaitu sebesar 1170.425 serta standar deviasinya sebesar 1834.089. 
Pada $\mathrm{H}+2$ nilai minimum sebesar 120.000 didapat oleh perusahaan Betonjaya Manunggal Tbk dan nilai maksimum sebesar 8925.000 diperoleh perusahaan Indofood CBP Sukses Makmur Tbk. Rata-rata harga saham relatif bernilai positif yaitu sebesar 1166.681 serta standar deviasinya sebesar 1843.822. Pada H+3 nilai minimum sebesar 120.000 didapat oleh perusahaan Betonjaya Manunggal Tbk dan nilai maksimum sebesar 8800.000 diperoleh perusahaan Indofood CBP Sukses Makmur Tbk. Rata-rata harga saham relatif bernilai positif yaitu sebesar 1175.106 serta standar deviasinya sebesar 1830.358 . Pada $\mathrm{H}+4$ nilai minimum sebesar 122.000 didapat oleh perusahaan Betonjaya Manunggal Tbk dan nilai maksimum sebesar 8800.000 diperoleh perusahaan Indofood CBP Sukses Makmur Tbk. Ratarata harga saham relatif bernilai positif yaitu sebesar 1175.276 serta standar deviasinya sebesar 1829.908. Pada H+5 nilai minimum sebesar 125.000 didapat oleh perusahaan Betonjaya Manunggal Tbk dan nilai maksimum sebesar 8850.000 diperoleh perusahaan Indofood CBP Sukses Makmur Tbk. Rata-rata harga saham relatif bernilai positif yaitu sebesar 1177.489 serta standar deviasinya sebesar 1833.416. Rata-rata harga saham relatif bernilai positif diperoleh pada setiap hari selama periode pengamatan. Rata-rata harga saham relatif tertinggi diperoleh pada Hari $\mathrm{H}$ dan rata-rata harga saham relatif terendah diperoleh pada saat $\mathrm{H}+2$ dan $\mathrm{H}+3$.

Tabel 2.

Deskripsi Data Trading Volume Activity

\begin{tabular}{lccccc}
\hline & N & Minimum & Maximum & Mean & $\begin{array}{c}\text { Std. } \\
\text { Deviation }\end{array}$ \\
\hline H-5 & 47 & 0.0000000 & 0.0051255 & 0.0005528 & 0.0011536 \\
H-4 & 47 & 0.0000000 & 0.0075581 & 0.0006756 & 0.0014940 \\
H-3 & 47 & 0.0000000 & 0.0076336 & 0.0006812 & 0.0014618 \\
H-2 & 47 & 0.0000000 & 0.0081736 & 0.0006796 & 0.0013737 \\
H-1 & 47 & 0.0000000 & 0.0091045 & 0.0007518 & 0.0014927 \\
H & 47 & 0.0000000 & 0.0126156 & 0.0009340 & 0.0020085 \\
H+1 & 47 & 0.0000000 & 0.0076920 & 0.0006948 & 0.0012999 \\
H+2 & 47 & 0.0000000 & 0.0073599 & 0.0007000 & 0.0015140 \\
H+3 & 47 & 0.0000000 & 0.0071915 & 0.0008613 & 0.0016768 \\
H+4 & 47 & 0.0000000 & 0.0077370 & 0.0008221 & 0.0016523 \\
H+5 & 47 & 0.0000000 & 0.0061339 & 0.0008233 & 0.0014391 \\
Valid N & 47 & & & & \\
(listwise) & & & & & \\
\hline Sumber: Data Diolah 2019 & & & & &
\end{tabular}

Sumber: Data Diolah 2019

Tabel 2. menjelaskan nilai maksimum, nilai minimum, rata-rata dan standar deviasi. Pada H-5 nilai minimum sebesar 0.0000000 didapat oleh perusahaan Akbar Indo Makmur Stimec Tbk dan nilai maksimum sebesar 0.0051255 diperoleh perusahaan Inti Agri Resources Tbk. Rata-rata trading volume activity bernilai positif yaitu sebesar 0.0005528 serta standar deviasinya sebesar 0.0011536 . Pada H-4 nilai minimum sebesar 0.000000 didapat oleh perusahaan Akbar Indo Makmur Stimec Tbk dan nilai maksimum sebesar 0.0075581 diperoleh perusahaan Totalindo Eka Persada Tbk. Rata-rata trading volume activity bernilai positif yaitu sebesar 0.0006756 serta standar deviasinya sebesar 0.0014940 .

Pada H-3 nilai minimum sebesar 0.0000000 didapat oleh perusahaan Akbar Indo Makmur Stimec Tbk dan nilai maksimum sebesar 0.0076336 diperoleh 
perusahaan Impack Pratama Industri Tbk. Rata-rata trading volume activity bernilai positif yaitu sebesar 0.0006812 serta standar deviasinya sebesar 0.0014618 . Pada H-2 nilai minimum sebesar 0.0000000 didapat oleh perusahaan Akbar Indo Makmur Stimec Tbk dan nilai maksimum sebesar 0.0081736 diperoleh perusahaan Inti Agri Resources Tbk. Rata-rata trading volume activity bernilai positif yaitu sebesar 0.0006796 serta standar deviasinya sebesar 0.0013737. Pada H-1 nilai minimum sebesar 0.0000000 didapat oleh perusahaan Akbar Indo Makmur Stimec Tbk dan nilai maksimum sebesar 0.0091045 diperoleh oleh perusahaan Inti Agri Resources Tbk. Rata-rata trading volume activity bernilai positif sebesar 0.0007518 serta standar deviasinya sebesar 0.0014927 .

Pada hari H nilai minimum sebesar 0.0000000 didapat oleh perusahaan Akbar Indo Makmur Stimec Tbk dan nilai maksimum sebesar 0.0126156 diperoleh perusahaan Mahaka Radio Integra Tbk. Rata-rata trading volume activity bernilai positif yaitu sebesar 0.0009340 serta standar deviasinya sebesar 0.0020085 . Pada $\mathrm{H}+1$ nilai minimum sebesar 0.0000000 didapat oleh perusahaan Akbar Indo Makmur Stimec Tbk dan nilai maksimum sebesar 0.0076920 diperoleh perusahaan Mahaka Radio Integra Tbk. Rata-rata trading volume activity bernilai positif sebesar 0.0006948 serta standar deviasinya sebesar 0.0012999 . Pada $\mathrm{H}+2$ nilai minimum sebesar 0.0000000 didapat oleh perusahaan Primarindo Asia Infrastr. Tbk dan nilai maksimum sebesar 0.0073599 diperoleh perusahaan Inti Agri Resources Tbk. Rata-rata trading volume activity bernilai positif sebesar 0.0007000 serta standar deviasinya sebesar 0.0015140 .

Pada H+3 nilai minimum sebesar 0.0000000 didapat oleh perusahaan Primarindo Asia Infrastr. Tbk dan nilai maksimum sebesar 0.0071915 diperoleh perusahaan Inti Agri Resources Tbk. Rata-rata trading volume activity bernilai positif sebesar 0.0008613 serta standar deviasinya sebesar 0.0016768 . Pada $\mathrm{H}+4$ nilai minimum sebesar 0.0000000 didapat oleh perusahaan Primarindo Asia Infrastr. Tbk dan nilai maksimum sebesar 0.0077370 diperoleh perusahaan Inti Agri Resources Tbk. Rata-rata trading volume activity bernilai positif sebesar 0.0008221 serta standar deviasinya sebesar 0.0016523 . Pada H+5 nilai minimum sebesar 0.0000000 didapat oleh perusahaan Primarindo Asia Infrastr. Tbk dan nilai maksimum sebesar 0.0061339 diperoleh perusahaan Mahaka Radio Integra Tbk. Rata-rata trading volume activity bernilai positif sebesar 0.0008233 serta standar deviasinya sebesar 0.0014391 . Rata-rata trading volume activity bernilai positif diperoleh pada setiap hari selama periode pengamatan. Rata-rata trading volume activity tertinggi diperoleh pada hari $\mathrm{H}$ sementara rata-rata trading volume activity terendah diperoleh setiap hari selama periode pengamatan

Berdasarkan Tabel 3 diketahui data berdistribusi tidak normal. Hal tersebut dapat dilihat dari nilai Asymp. Sig. (2-tailed) harga saham relatif sebelum dan sesudah peristiwa stock split lebih kecil dari taraf signifikansi $\alpha=5 \%(0,001<0,05$ dan $0,000<0,05)$ sehingga alat uji hipotesis yang digunakan yaitu uji non parametrik wilcoxon signed rank test.

Berdasarkan Tabel 4. diketahui data berdistribusi tidak normal, hal tersebut dapat dilihat dari nilai Asymp. Sig. (2-tailed) trading volume activity sebelum dan sesudah peristiwa stock split lebih kecil dari taraf signifikansi $\alpha=5 \%(0,001<0,05$ 
dan $0,000<0,05)$ sehingga alat uji hipotesis yang digunakan yaitu uji non parametrik wilcoxon signed rank test.

Tabel 3.

Hasil Uji Normalitas Harga Saham Relatif Sebelum dan Sesudah

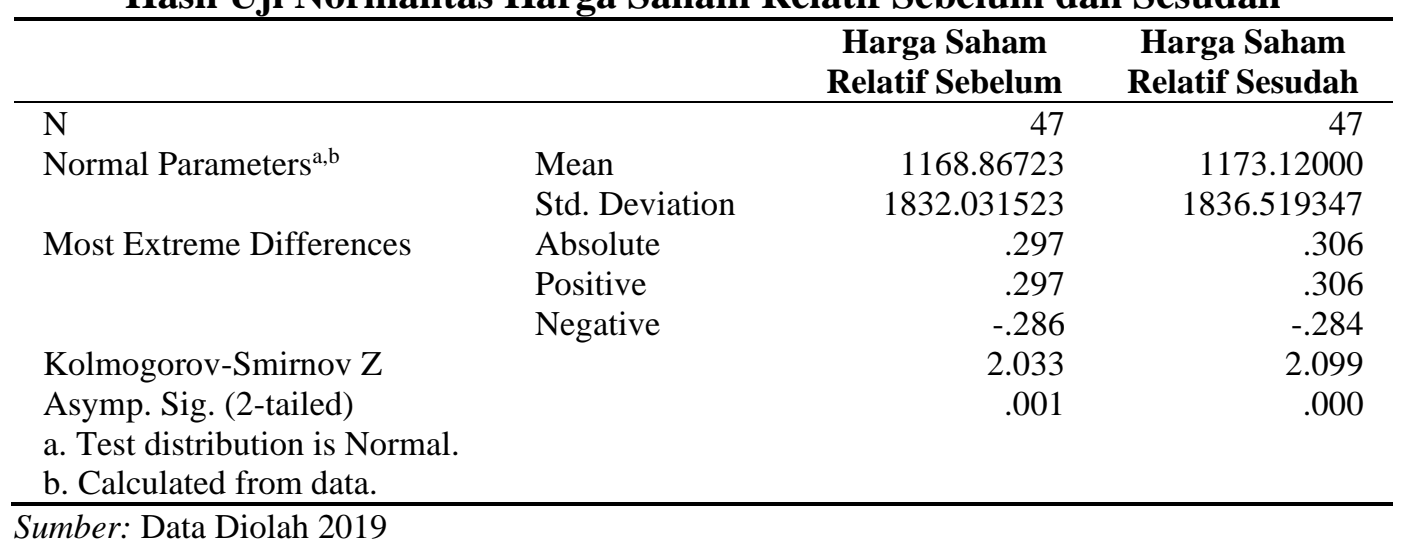

Tabel 4.

Hasil Uji Normalitas Trading Volume Activity Sebelum dan Sesudah Stock Split One-Sample Kolmogorov-Smirnov Test

\begin{tabular}{llrr}
\hline & & TVA Sebelum & \multicolumn{1}{c}{ TVA Sesudah } \\
\hline $\mathrm{N}$ & & 47 & 47 \\
Normal Parameters ${ }^{\mathrm{a}, \mathrm{b}}$ & Mean & .000667196 & .000822755 \\
& Std. Deviation & .0011899194 & .0015505775 \\
Most Extreme Differences & Absolute & .287 & .298 \\
& Positive & .256 & .266 \\
& Negative & -.287 & -.298 \\
& & 1.971 & 2.043 \\
Kolmogorov-Smirnov Z & .001 & .000 \\
Asymp. Sig. (2-tailed) & & & \\
a. Test distribution is Normal. & & & \\
b. Calculated from data. & & & \\
Sumber: Data Diolah 2019 & &
\end{tabular}

Tabel 5.

Uji Wilcoxon Signed Rank Test Harga Saham Relatif

\begin{tabular}{lr} 
& $\begin{array}{c}\text { Harga Saham Relatif Sesudah - } \\
\text { Harga Saham Relatif Sebelum }\end{array}$ \\
\hline $\mathrm{Z}$ & $-2.169^{\mathrm{b}}$ \\
Asymp. Sig. (2-tailed) & .030 \\
\hline
\end{tabular}

Sumber: Data Diolah 2019

Berdasarkan hasil uji hipotesis tersebut didapatkan signifikansi $0.030<0.05$ sehingga diperoleh bahwa $\mathrm{H}_{1}$ diterima atau terdapat perbedaan yang signifikan ratarata harga saham relatif sebelum dan sesudah stock split.

Berdasarkan hasil uji hipotesis tersebut didapatkan signifikansi $0.575>0.05$ sehingga diperoleh bahwa $\mathrm{H}_{2}$ ditolak atau tidak terdapat perbedaan yang signifikan rata-rata trading volume activity sebelum dan sesudah stock split. 
Tabel 6.

Uji Wilcoxon Signed Rank Test Trading Volume Activity (TVA)

\begin{tabular}{lrr} 
& \multicolumn{2}{c}{ TVA Sesudah Stock Split - TVA Sebelum } \\
& \multicolumn{2}{c}{ Stock Split } \\
\hline Z & $-.561^{\mathrm{b}}$ \\
Asymp. Sig. (2-tailed) & .575 \\
\hline
\end{tabular}

Sumber: Data Diolah 2019

Hasil hipotesis 1 menyatakan bahwa terdapat perbedaan signifikan rata-rata harga saham relatif sebelum dan sesudah stock split. Hasil ini menunjukkan bahwa penelitian ini konsisten dengan signaling theory yang berargumen bahwa stock split menunjukkan sinyal optimisme manajemen akan mampu meningkatkan kembali harga saham dimasa yang akan datang. Hal ini ditunjukkan dengan adanya kenaikan harga saham yang signifikan menjelang peristiwa pemecahan saham hingga pasca pemecahan saham. Kenaikan harga saham tertinggi terjadi pada $\mathrm{H}-1$ sebelum peristiwa stock split. Ini menandakan bahwa pasar memberikan respon yang cepat ketika H-1 sebelum stock split sehingga menyebabkan peningkatan harga saham. Penyebabnya yaitu adanya kenaikan aktivitas volume perdagangan saham menjelang peristiwa pemecahan saham yaitu dari $\mathrm{H}-5$ hingga $\mathrm{H}-2$ walaupun tidak signifikan yang dapat menyebabkan terjadinya kenaikan harga saham sehingga mencapai rata-rata harga tertinggi ketika $\mathrm{H}-1$ sebelum peristiwa stock split. Hasil pengujian hipotesis 1 menjelaskan bahwa pemecahan saham yang dilakukan oleh emiten memberikan dampak yang berarti terhadap harga pasar saham relatif. Hasil penelitian ini mendukung penelitian yang dilakukan oleh Arifandi (2014) dan Fauzi dkk. (2016) yang memperoleh hasil yang sama yakni terdapat perbedaan yang signifikan harga saham relatif sebelum dan sesudah stock split.

Hasil hipotesis 2 menyatakan bahwa tidak terdapat perbedaan yang signifikan trading volume activity sebelum dan sesudah stock split. Rata-rata TVA tertinggi diperoleh pada saat hari $\mathrm{H}$ pemecahan saham. Hal tersebut berarti bahwa aktivitas volume perdagangan tertinggi diperoleh ketika hari $\mathrm{H}$ pemecahan saham. Hal ini dapat terjadi karena pasar memperoleh informasi kenaikan harga saham yang cukup signifikan pada $\mathrm{H}-1$ sebelum peristiwa pemecahan saham sehingga muncul harapan investor bahwa dengan melakukan pembelian saham tersebut, dapat memberikan laba bagi investor pasca split sehingga terjadi peningkatan aktivitas volume perdagangan saham pada hari $\mathrm{H}$ pemecahan saham. Namun, ketika hari $\mathrm{H}$ pemecahan saham, harga saham justru mengalami penurunan. Hal tersebut menyebabkan aktivitas volume perdagangan saham pada hari $\mathrm{H}$ menurun.

Maka dari itu, disimpulkan bahwa para investor tidak mendapatkan adanya sinyal positif yang dikeluarkan oleh emiten. Pengumuman stock split ini dianggap bukanlah sebagai good news bagi para investor sehingga mengakibatkan kurangnya minat investor untuk melakukan transaksi. Kebijakan stock split juga dianggap sebagai sebuah informasi yang pada dasarnya tidak memiliki nilai ekonomis ditafsirkan oleh investor sebagai dua kemungkinan yaitu kabar baik dan kabar buruk. Ketidakseimbangan informasi (information asymetry) ini mengindikasikan adanya ketidakpastian yang lebih tinggi yang dialami investor sehingga para investor ragu-ragu untuk melakukan transaksi yang lebih tinggi. Sehingga hal 
tersebut menyebabkan tidak ada perbedaan yang signifikan aktivitas volume perdagangan saham sebelum dan sesudah stock split.

Hasil penelitian ini mendukung penelitian yang dilakukan oleh Mahala dkk. (2015), Khajar (2016) serta Fauzi dkk. (2016) yang menyimpulkan bahwa tidak terdapat perbedaan yang signifikan antara volume perdagangan saham sebelum dan sesudah stock split. Pengumuman stock split ini dianggap bukanlah sebagai good news bagi para investor sehingga mengakibatkan kurangnya minat investor untuk melakukan transaksi.

Harga pasar saham relatif sebelum pemecahan saham merupakan perbandingan antara harga saham sebelum stock split dengan hasil perbandingan antara nilai nominal saham sebelum stock split dengan nilai nominal saham setelah stock split. Harga pasar relatif setelah pemecahan saham merupakan harga yang dibentuk dari interaksi para penjual dan pembeli saham yang terjadi setelah stock split. Hasil penelitian ini mengindikasikan implikasi bahwa terdapat perbedaan harga saham relatif sebelum dan sesudah stock split yang berarti bahwa peristiwa stock split memberikan dampak terhadap harga saham. Hal ini dapat dilihat dengan adanya kenaikan maupun penurunan harga saham yang cukup signifikan.

Trading volume activity merupakan rasio antara jumlah lembar saham yang diperdagangkan pada waktu tertentu terhadap jumlah lembar saham yang beredar pada periode waktu tersebut. Trading volume activity digunakan untuk melihat aktivitas perdagangan saham oleh suatu perusahaan. Hasil penelitian ini menunjukkan bahwa tidak terdapat perbedaan yang signifikan trading volume activity sebelum dan setelah peristiwa stock split. Hal ini menandakan bahwa peristiwa stock split tidak memberikan dampak yang signifikan terhadap aktivitas volume perdagangan saham. Peristiwa stock split tidak dianggap sebagai sinyal positif oleh para investor yang berarti bahwa berita tersebut tidak diterima sebagai good news. Investor menganggap berita ini sebagai sebuah informasi yang pada dasarnya tidak memiliki nilai ekonomis ditafsirkan oleh investor sebagai dua kemungkinan yaitu kabar baik dan kabar buruk. Ketidakseimbangan informasi (information asymetry) ini mengindikasikan adanya ketidakpastian yang lebih tinggi yang dialami investor sehingga para investor ragu-ragu untuk melakukan transaksi yang lebih tinggi sehingga dapat dilihat dari rata-rata perhitungan trading volume activity yang tidak mengalami perbedaan yang signifikan.

\section{SIMPULAN}

Hasil pengujian harga saham sebelum dan setelah stock split menunjukkan bahwa adanya perbedaan harga saham sebelum dan sesudah stock split. Hal ini menunjukkan bahwa peristiwa stock split memberikan dampak yang signifikan terhadap harga saham yang dapat dilihat dengan adanya perbedaan harga saham sebelum dan sesudah stock split. Hasil penelitian ini mendukung trading range theory dimana dengan adanya pemecahan saham, harga saham menjadi tidak terlalu tinggi sehingga banyak investor yang mampu melakukan transaksi, yang dapat menaikkan harga saham.

Hasil pengujian trading volume activity sebelum dan setelah stock split menunjukkan bahwa tidak terdapat perbedaan yang signifikan trading volume 
activity sebelum dan sesudah stock split. Hal ini menunjukkan bahwa peristiwa stock split tidak memberikan dampak yang signifikan terhadap aktivitas volume perdagangan saham yang ditunjukkan oleh tidak adanya perbedaan yang signifikan trading volume activity sebelum dan setelah stock split. Peristiwa stock split tidak dianggap sebagai sinyal positif oleh para investor yang berarti bahwa berita tersebut tidak diterima sebagai good news. Investor menganggap berita ini sebagai sebuah informasi yang pada dasarnya tidak memiliki nilai ekonomis yang ditafsirkan oleh investor sebagai dua kemungkinan yaitu kabar baik dan kabar buruk. Ketidakseimbangan informasi (information asymetry) ini mengindikasikan adanya ketidakpastian yang lebih tinggi yang dialami investor sehingga para investor raguragu untuk melakukan transaksi.

Bagi investor, dalam melakukan keputusan investasi sebaiknya para investor memperhatikan berita/informasi mengenai kebijakan-kebijakan yang dikeluarkan oleh perusahaan seperti pengumuman pemecahan saham karena dengan adanya informasi pemecahan saham tersebut investor dapat menggunakannya sebagai acuan untuk mengambil keputusan investasi yang tepat guna memperoleh keuntungan. Hal yang tidak kalah penting ialah investor juga harus mempertimbangkan faktor-faktor eksternal seperti faktor ekonomi dan politik, kondisi pasar dan lain-lain. Ini dikarenakan faktor-faktor tersebut secara tidak langsung akan mempengaruhi harga saham.

Bagi emiten, hasil penelitian ini memberikan masukan bagi emiten bahwa kebijakan stock split tidak menjamin bahwa harga saham akan terus meningkat sesuai dengan tujuannya. Hal ini dikarenakan terdapat faktor-faktor yang melatarbelakanginya seperti ketidakstabilan politik dan ekonomi serta faktor lainnya. Selain itu, kebijakan ini juga terbukti tidak mampu meningkatkan aktivitas volume perdagangan saham sehingga emiten sebaiknya tidak hanya melakukan corporate action berupa stock split untuk meningkatkan likuiditas perdagangan sahamnya. Bagi peneliti selanjutnya, diharapkan dapat mengembangkan penelitian ini dengan meneliti dampak stock split berdasarkan sektor. Penelitian per sektor ini diharapkan dapat menghasilkan temuan yang lebih akurat, karena Sembilan sektor perusahaan yang ada di Bursa Efek Indonesia memiliki karakteristik yang berbeda.

\section{REFERENSI}

Anggraini, N. P. D., \& Ni Luh Putu Wiagustini. (2015). Dampak Pemecahan Saham Terhadap Likuiditas dan Abnormal Return di Bursa Efek Indonesia. E-Jurnal Manajemen Universitas Udayana, 4(3), 643-658.

Azis, M., \& Nadir. (2015). Manajemen Investasi Fundamental, Teknikal, Perilaku, Perilaku Investor dan Return Saham. Yogyakarta: CV. Budi Utama.

Bhuvaneswari, \& Ramya, K. (2014). Impact Of Stock Split Announcement On Stock Prices. International Journal of Management, 5(3), 33-46.

Darmadji, T., \& Hendy M., F. (2012). Pasar Modal Indonesia: Pendekatan Tanya Jawab. Jakarta: Salemba Empat.

Dwimulyani, S. (2018). Analisis Pemecahan Saham (Stock Split): Dampaknya 
tehadap Likuiditias Perdagangan Saham dan Pendapatan Perusahaan Publik di Indonesia. Jurnal Informasi, Perpajakan, Akuntansi, Dan Keuangan Publik, $3(5), 12-15$.

E.D, A. (2014). Analisis Perbedaan Harga Saham Sebelum dan Sesudah Stock Split Pada Perusahaan Manufaktur yang Terdapat di Bursa Efek Indonesia. Jurnal Manajemen Keuangan, 7(3), 9-12.

Fauzi, S. Z., Suhadak, \& R. Rustam Hidayat. (2016). Pengaruh Pengumuman Stock Split Terhadap Likuiditas Saham dan Return Saham. Jurnal Administrasi Bisnis, 8(2), 25-32.

Gajera, A., Mansata, P., \& Shreya, V. (2017). Risk and Return Analysis of Selected Stock Before and After Split. Internasional Journal for Innovative Research in Multidisciplinary Yield, 6(4), 17-24.

Gao, D., \& Zhiyu An. (2018). Impact of Stock Split on Rate of Stock Return in China A-share Market. Advances in Economics, Business and Management Research, 3(8), 11-17.

Ginting, S. ., \& Rahyuda, H. (2014). Perbedaan Volume Perdagangan Saham dan Abnormal Return Sebelum dan Sesudah Peristiwa Stock Split Pada Perusahaan di Bursa Efek Indonesia. E-Jurnal Manajemen Universitas Udayana, 3(6), 1571-1589.

Hossain, Md., S. (2017). Market Reaction around the Event of a Stock Split: An Analysis on the Dhaka Stock Exchange. IJBM Canadian Center of Science and Education, 4(3), 5-9.

Hua, W. S., Xiao, Q. S., Xue, Q. C., \& Yuqing, Z. (2016). Market Confidence Predict Stock Price: Beyond Supply and Demand. Plosone, 11(7), 1-10.

Jaelani. M. (2013). Stock Split Policy on Signal and Liquidity Motive with Implications to Retail Investor. International Journal of Science and Research, 2(6), 426-431.

Jasmine, A. V., \& Leo Herlambang. (2015). Reaksi Pasar Atas Stock Split Pada Emiten Saham Syariah di Bursa Efek Indonesia Periode 2011-2014. Jurnal Ekonomi Syairah Teori Dan Terapan, 2(8), 658-672.

Jay, D. (2016). Impact of Stock Split on Share Price. International Journal of Recent Scientific Research, 7(5), 11419-11422.

Jyoti, M. (2014). Dampak Masalah Bonus terhadap Harga Saham Perusahaan. Jurnal Internasional Penelitian Keuangan \& Pemasaran, 4(2), 29-37.

Kemraj, T., \& Sukrishnalall, P. (2014). The Determinant of Bird-Ask Spread in the Guyanese FX Market. The Journal of Developing Areas, 48(2), 31-37.

Kesuma, S., \& Adnan. (2018). Analisis Peristiwa Stock Split Terhadap Harga Saham, Likuiditas, dan Abnormal Return (Studi Kasus Pada Perusahaan Manufaktur Yang Terdaftar di Bursa Efek Indonesia Tahun 2011-2018 
Akuntansi (JIMEKA). Jurnal Ilmiah Mahasiswa Ekonomi, 3(3), 364-384.

Khajar, I. (2016). Analisis Stock Split Terhadap Harga Saham dan Volume Perdagangan Saham Indek LQ-45 Periode 2010-2016. Jurnal Keuangan Dan Perbankan, 2(3), 11-16.

Korir, S. K., Albert Onyango Odhiambo, \& Peter Wawirec. (2016). Stock Splits and Performance of Firms Listed at the Nairobi Securities Exchange, Kenya. International Journal of Sciences, 29(2), 168-178.

Mahala, F. L., Zahroh, \& Dwiatmanto. (2015). Analisis Harga Saham Sebelum dan Sesudah Stock Split. Jurnal Administrasi Bisnis, 25(3), 27-36.

Masry, M. (2015). The Impact of Stock Split on Stock Prices in the Egyptian Stock Market. Research Journal of Finance and Accounting, 6(20), 116-135.

Mediyanto, M. E. (2015). Pengaruh Stock Split terhadap Abnormal Return dan Volume Perdagangan Saham. Artikel Ilmiah Mahasiswa, 3(4), 1-7.

Mittal, D. S. (2015). Stock Market Reactions to Announcement of Stock Split. Journal of Management Sciences and Technology, 2(2), 52-58.

Nadig, A. (2015). An Emperical Study of Stock Split Announcement of Select BSE Sector using Event Study Methodology. Journal of Management, 3(1), 1-12.

Osama, A. El, \& Mervat, H. (2017). The Impact of Stock Dividends and Stock Split on Shares Price: Evidence from Egypt. Accounting and Finance Research, 6(4), 96-114.

Patel, M., Munjal, D., \& Mayur, S. (2016). Stock Price and Liquidity Effect of Stock Split: Evidence from India Market. Internasional Journal of Management Research and Review, 5(4), 15-19.

Safira, T. H., \& Febriyanti, S. (2016). Uji Komparasi Abnormal Return, Trading Volume Activity, Trading Frequency, dan Bid Ask Spread Sebelum dan Sesudah Share Split (Studi Pada Perusahaan Yang Terdaftar di BEI periode 20011-2015). Ultima Accounting, 8(2), 17-26.

Setiawan, A., \& Atikah. (2018). Does Stock Split Influence to Liquidity and Return? (Emperial Evidence in the Indonesian Capital Market). Asian Economic and Financial Review, 6(3), 23-34.

Sudirman. (2015). Pasar Modal dan Manajemen Portofolio. Gorontalo: Sultan Amai Press.

Tabibian, S. A. (2014). The Effect of Stock Split on Stock Return: Evidence from Malaysia. Graduate School of Business, National University of Malaysia., 6(3), 29-36.

Tandelilin, E. (2010). Portofolio dan Investasi. Yogyakarta: CV. Kanisius.

Utami, A. S. (2017). Analisis Trading Volume Activity dan Average Abnormal 
Ni Kadek Wiwik Yuniartini, Dampak Stock Split...

Return Sebelum dan Sesudah Melakukan Pemecahan Saham (Stock split) Pada Perusahaan yang Terdaftar di Bursa Efek Indonesia. Jurnal Ekonomi Bisnis, 2(3), 35-44.

Yustisia, N. (2018). The Impact of Stock Split on The Performance in Indonesian Manufackuring Companies. Binus Business Review, 6(8), 22-38.

Zeky, S. (2018). Analisis Pengaruh Stock Split Terhadap Harga Saham dan Volume Perdagangan. Fakultas Ekonomi Dan Bisnis Universitas Islam Malang, 7(12), 41-44. 